\title{
Suffering, as a testimony of freedom
}

\author{
Assoc. Prof. PhD. Leontin POPESCU, \\ Faculty of History Philosophy and Theology \\ "Dunărea de Jos" University of Galați, \\ ROMANIA \\ E-mail: prleonpopescu@yahoo.it
}

\begin{abstract}
There is almost no thinker in the history of mankind not to be interested in the issue of evil and suffering that accompany man's life from his birth to his death, just like the shadow never separates from the body. Everybody has tried to unlock this mystery, to reach a deep understanding of it, to uncover its meanings, to identify ways to remove it or, at least, to make it less of an experience. And, in this respect, one may say that pain, suffering and fear of death make up the most profound anthropological basis of the religious concept of life by the fact that these realities show man his limitations, his finite constitution, that of a creature, thus driving him to search beyond his limitations. From this point of view, the suffering of each and every man, assessed individually, may be considered as the paradigm for a history of mankind and this is possible only because suffering is inseparably linked to existence.
\end{abstract}

Keywords: suffering; illness; sacrament; experience; healing; martyr;

\section{INTRODUCTION}

Suffering has been and will be talked about until the end of time. It is our historical condition, it encompasses us, it sometimes overwhelms us, it makes us anxious, frustrated, and rebellious. We are born through suffering and we continue to experience it during our lives. Death itself is often looked upon as suffering. The fear of suffering and, generally, the philosophical reflection on the meaning of suffering have always given rise to one of the greatest questions of mundane human existence disseminated in each historical epoch: what for? why is suffering necessary? which are the reasons for its existence? What is the meaning of suffering when confronted with the fundamental and central belief of mankind's religious consciousness, namely how does it relate to the existence of God? Isn't there an irreconcilable difference between existence in suffering and the existence of God believed to be both Good and Omnipotent? Moreover, suffering invalidates the very plan of creation, where "everything was very good" and there was no room envisioned for pain or evil. And in more serious terms, how can one reconcile the suffering of an innocent person and the kindness and omnipotence of $\mathrm{God}^{1}$, who is called Father? These are the questions that man has faced along his existence on Earth and on which he has spent very much time, thought and material things, hoping to find an answer. Testimonies are to be found in the various successful or unsuccessful attempts at providing answers from within the history of religions, philosophy, literature and varied human expressive arts during the centuries. Over

\footnotetext{
${ }^{1}$ Dionigi TettamanZI, Nuova Bioetica Cristiana / New Christian Bioethics, Turin, Piemme, 2001, p. 347.
} 
the time, many religious and philosophical systems have tried to satisfactorily clear up the issue of suffering. Many have attempted to provide a way out of suffering, a sort of redemption by avoiding it. A case in point is the Buddhist way. Noticing that the entire existence is suffering ${ }^{2}$, that, in fact, the very existence means suffering to the point where it identifies with it, they reached the conclusion that the best solution is to flee ${ }^{3}$, liberating themselves from suffering by liberating themselves from existence. Taking refuge into nothingness, into non-existence, constitutes the only variant for Buddhist thinking in particular, and for the extreme Orient one in general. For the contemporary man, suffering cannot have any spiritual explanation. He looks upon it as natural decay, which does not require any motivation or spiritual explanation; this is why the solution is also natural. Man can find no meaning in it, considers it absurd and identifies his life not with understanding it, but with struggling to avoid it ${ }^{4}$.

On the contrary, Christianity focuses very much on courage, on responsibility and redemption without losing one's identity. Christianity itself is the religion of courage, as true courage implies hope. Courage does not mean quitting when you feel you can't win, but fighting against all the odds that would indicate defeat.

\section{SUFFERING AS A TEST OF FREEDOM}

We know that suffering inseparably accompanies human existence because of the consequences of the primordial sin on the human nature and then on the entire nature created. Man bears within (himself) this sprout that, due to freedom, can bring about not only suffering and death, but also holiness. To do this, we must distinguish among several types of human experience when we talk about suffering, namely there is physical suffering, of the body, that man experiences through illness, despair and death; there is moral suffering, of the soul, more heart-wrenching than the physical one, caused by discontent, bereft, betrayal, disdain and even one's own mistakes; there is psychological suffering, which often acts as a consequence of physical and moral pain, and which becomes manifest in sadness - the acedia that the Holy Fathers talk about, pessimism, discouragement, depression. Thus, there is one thing to experience physical suffering, and a totally different one to experience what we generically call moral suffering, which encompasses sadness and depression, that can only be cured by having man relate to his spiritual nature and find himself as a person in a dialogue with the transcendent ${ }^{5}$.

In other words, when we talk about physical suffering, we think of the body, and, when we talk about moral suffering, we think of the soul. Sometimes, such instances of experiencing suffering overlap, turning into a real social whip, as we can see in the case of natural calamities, pandemics, catastrophe, hunger and war. It is enough, in order to understand the existence of all these forms of human experience of suffering, to think about the extermination of Jews in Nazi camps, about the atomic bombs at Hiroshima and

\footnotetext{
${ }^{2}$ Aldo NATALE TERRIN, "Il dolore e la morte nelle religioni" / "Suffering and Pain in Religions," in: Sensul vieții, al suferinței și al morții / The Meaning of Life, Suffering and Death, Alba-Iulia International Symposium, February 29 februarie - March 2, 2008, Alba-Iulia, Reîntregirea Publishing House, 2008, p. 57-69, here pp. 63-64.

${ }^{3}$ Maurizio CHIODI, Etica de la Vita / The Ethics of Life, Milano, Edizioni Glossa, 2006, p. 309.

${ }^{4}$ George ReMETE, Suferinţa omului şi iubirea lui Dumnezeu / Man's Suffering and God's Love. Bucharest, Edit. Institutului Biblic și de Misiune al Bisericii Ortodoxe Române / The Biblical and Romanian Orthodox Church Mission Institute (from now on BROCMI), 2005, p. 11.

${ }_{5}^{5}$ Hierotheos Vlachos, Psihoterapie ortodoxă - continuare și dezbateri / Orthodox Psychotherapy continuation and debates, Bucharest, Sophia, 2007, p. 148.
} 
Nagasaki, about ethnic purge, about the abuses committed against millions of innocent children. All these forms of suffering are only particular aspects of the general issue of "evil," which consists in people being deprived of the good. We are aware that God is not the cause of the evil and the suffering in our lives, but, surely, they are allowed to happen by His Divine Providence. A nagging question arises: why does God allow man, the most beautiful of all creatures, to wallow in adversity, suffering, pain and death? It is very difficult for us to grasp, every time, the real cause of suffering, and this happens because illness and pain hurt the individual in his most intimate experience.

The suffering man must experience inner conflict: how he must understand himself. Using this as a starting point, we must interpret the meaning of suffering. Of course, the question to be asked is exactly this: what is the meaning of suffering? where must we look for this meaning? what is suffering, after all? And if we think from the perspective of a life of faith: why is there suffering in the world, at all, if Christ abolished it by restoring human nature? Here are so many interrogations that require an interpretation of the meaning of suffering. Mention must be made from the very beginning that bodily suffering can never bring about the death of the soul ${ }^{6}$, not even moral suffering can cause that, nor can guilt for sins committed lead to the destruction of the soul. This can only be done by God. But if the soul is suffering, the body is in the same state: it forgets about what is necessary to preserve the biological balance of the individual. And vice versa, if the body is suffering, the soul is suffering as well. Thus, experiencing suffering always addresses the conscience that feels the spiritual and the physical pain to the same extent ${ }^{7}$. In this case, this is not about just a theoretical interpretation. From the point of view of the sufferer, we can notice an experience whose meaning focuses on loss, on failure and collapse of $\operatorname{man}^{8}$, of his values, similar to being deprived of everything he was supposed to accomplish in life, slavery, being resigned, somewhat observing the remarks of the supporters of the Antiquity philosopher, Epicurus, who considered illness and pain as a lack of or a void in the soul ${ }^{9}$, but, on the contrary, suffering must be looked upon as an event that must be lived as an experience of checking, of testing freedom, which reveals the path of hope in living one's life. It is true, suffering places man in crisis, but this crisis does not speak to man only about difficulties, fears and the end, but appeals to what is most profound in man, that is he is called to test himself to see how far or how long or how much he is willing to live as a man, even when experiencing suffering, illness and death ${ }^{10}$.

Physical and/or moral pain, particularly experienced over longer time, causes in man a certain state of suffering, which establishes that so-called status of man during suffering. This Status of illness or of being sick, at the deepest level, within, can bring about the following experiences ${ }^{11}$ : a) - experiencing a break from objectivity, a tear between thought and the suffering body, causing a feeling of otherness and alienation manifested in

\footnotetext{
${ }^{6}$ J. C. LARCHET, Dumnezeu nu vrea suferința omului / God Doesn't Want Man's Suffering, p. 104.

${ }^{7}$ M. CHIODI, Etica de la Vita / The Ethics of Life, p. 360.

${ }^{8}$ D. TetTAMANZI, Nuova Bioetica ... / New Christian Bioethics, p. 350.

${ }^{9}$ Paul Ricoeur, Flosofia della volonta. 1.Il voluntario e l'involuntario / The Philosophy of Will. 1. The Voluntary and the Involuntary, Genova, Marietti, 1990, p. 107-112.

${ }^{10}$ D. TettamanzI, Nuova Bioetica ... // New Christian Bioethics, p. 353.

11 Ioan C. TEȘU, "Necazurile, durerile și suferințele - forme ale iubirii milostive a lui Dumnezeu" "Misfortunes, Pain, and Suffering - Forms of God's Merciful Love, in "Teologie și Viața" / "Theology and Life", no. 9-12 (2012), p. 5-26, here, p. 6; also see: Pavel CHRILĂ \& com, Principii de bioetică. O abordare ortodoxă / Principles of Bioethics. An Orthodox Approach, Bucharest, Christiana Publishing House, 2008, p. 143.
} 
an inner lack of harmony; b) - when interacting with other people or other things, the sick person experiences, during the status of the illness, a communication and interpersonal relation crisis. Interested in himself, the sick person's universe is reduced to his own room; c) - suffering provides an intense experience of one's own life limit, quality and duration, limit that brings forth the idea of death at the level of the consciousness; d) - experiencing a feeling of being bereft, abandoned, which allows for experiencing sadness, existential emptiness, fear. The suffering that each man experiences directly challenges and tests freedom, and particularly hope, patience, and faith. The Holy Fathers emphasize that both bodily and spiritual suffering equally benefit man when he endures, being content. This is how Saint John Chrysostom advises Olympias the Deaconess: "Don't lose hope! Only one thing is frightening, Olympias, only one trouble must we fear: sin!" ${ }^{12}$ and he continues in a letter to the same Olympias:

\begin{abstract}
"Think these over, you as well! And the fuller life is of pain, the more you will have to gain if you endure all while being content. Much reward is to be found not only in bodily pain, such as hits, but also in spiritual pain; and suffering of the soul so much more than that of the body, when the hurt ones endure them while being content. The same way you would be richly rewarded if, for the glory of God, you courageously put up with being whipped or with having your body torn apart, great reward awaits you for the spiritual suffering you are experiencing now. Keep hoping, and you will undoubtedly see again that you will be rid of that pain and you will gain a lot, both then and now, from this pain"13 . [...] Because enduring illness is the highest form of patience" ${ }^{14}$. [...] You? You must rejoice and be happy, for you have exerted the greatest of all virtues, the virtue of virtues. You know, you know well that no virtue equals patience, it is the queen of virtues, the foundation of good deeds, the clear safe haven, peace during war, the calm after the storm, strength amidst plots. Patience makes you tougher than diamonds. Patience cannot be overcome by any sort of weapons, or armies, or war machineries, or arrows, or spears, or legions of demons, or the dangerous phalanges of enemy powers, or even by the devil, with all his army and wit. Then, why are you afraid? Why do you grow sad, when you are ready to lay down your life, if circumstance required? You keep saying that you want to see an end to the evil around you? You will see the end of them as well! You will see it soon, God willing! Dare, thus, to enjoy your good deeds! Don't ever lose hope" ${ }^{\text {, }}$.
\end{abstract}

\footnotetext{
${ }^{12}$ St. John Chrysostom, Epistolae ad Olympiadem, in J.P. Migne, PG. 52, col. 542-623, here col. 549: "Entenim una dumtaxat res gravis ac pertimescenda est, o Olympias, una tentatio, nempe peccatum".

${ }^{13}$ Ibidem, col. 571-572: "Haec igitur ipsa tecum perpetuo meditare, et quo ea res cruciatum tibi maiorem affert, eo etiam eam, si grato animo feras, maiorem fructum allaturam esse existima. Non enim corporeae dumtaxat plagae illatae, sed etiam animi dolor omni sermone sublimiores coronas affert, et quidem animi dolor magis quam corporis, cum qui feriuntur, cum gratiarum actione ferunt. Quemadmodum igitur si corpore lacerata verberibusque concisa, forti ac generoso animo id ferres, Deique gloriam hoc nomine praedicares, ingentem hinc mercedem consequereris: eodem modo, cum haec animus tuus patiatur, magna hinc praemia exspecta.Expectes vetim etiam fore omnio, ut rursum nos videas, atque hoc dolore llibereris, amplumque et uberem huius doloris quaestrum, et post hac et nunc, percipias."

${ }^{14}$ Ibidem, col. 592 : "Hoc omnibus rebus adversis gravis esse, ac summus patientiae genus"

15 Ibidem, col. 606-607: "Te vero exsultare ac laetitia diffundi convenit, quia quod virtutum caput est praestitisti. Nosti etiam, nostri profecto nihil esse quod patientiam adaequare possit, verum ippsam potissimum virtutum reginam esse, rerum praeclare gestarum fundamentum, portum tranquillum, in bello pacem, in tempestate tranquillitatem, in insidiis securitatem: quae sectatorem suum adamante firmiorem reddit, hanque naturam habet, ut eam nec arma mota, nec instructi exercitus, nec adhibita tormenta, nec arcus, nec lanceae emissae, nec ipsum daemonum agmen, nec terrificae adversariarum potestatum phalanges, nec denique diabolus ipse cum omnibuz suis copiis machinisque in aciem prodiens, detrimento ullo afficere possit. Quid igitur extimescis? Quid excruciaris, cum ipsam quoque vitam, si tempus postularit, aspernari dinturna meditatione didiceris? At urgentium malorum finem cupis. Erit quoque istud, quidem brevi, Deo concedente. Gaude igitur et oblectare, atque cogitandis tuis recte factis animum exhilara: nec umqam dispera." Cfr. ST.
} 
More than suffering itself, there are three things that erode the peace of the suffering man: experience, challenge, and time, duration of suffering. This is why the most frequent understanding of suffering is that it must be grasped as a challenging experience during one's lifetime. Suffering is, above all, a test, because it seems to create a negative, sterile and futile outlook of human aspiration towards happiness and a good life, overlapping moral pain over the physical one ${ }^{16}$. It is human nature to look for the good, or, better said, to try and feel well, to share only what one likes. Suffering can cause tremendous emptiness within the soul. But suffering is not its cause, but the way in which we look at reality and perceive it as such. Saint Augustine tells us that accepting or coming to terms with the state of suffering is not the same for all people:

\begin{abstract}
"The same way fire makes gold shine and foam evaporate, the same way yeast and oil do not mix in the same press, the same way the thrasher crushes the straw but peels the wheat, the same fate tests, purifies and sanctifies the good, sentences and destroys the bad. This is why, while experiencing the same suffering, the bad curse God, while the good bless His word. The wind blows over garbage and spreads its smell, but it also blows over the lily and spreads its perfume" ${ }^{, 17}$.
\end{abstract}

When suffering, conscience is made to look at some "beyond," as a limit and, in a challenging way, it questions the promise to live: understand and discover the solitude and the individualism of existence, the ontological poverty and emptiness ${ }^{18}$. Pain and suffering can create the opportunity of opening a door to a world that we couldn't see, or which was not made for our immediate interest. A new existence is born through pain ${ }^{19}$. The question that arises is not how we can eliminate pain, but how we can succeed in living in pain. The sense of suffering does not reside in the fact that someone is suffering, but in how they are suffering, and this understanding will never be found in an appeal to immanence, but always in an appeal to transcendence ${ }^{20}$. Ultimately, it is a test of faith, which is called to decide upon the existential, final questions. Seen from this perspective, suffering becomes an unexpected master that propositions man's freedom to face the challenge of experiencing suffering ${ }^{21}$. Suffering, as a challenge, offers the possibility of two paths to take, which are not equivalent: the former is that of denial, of rejecting any meaning for the existence of suffering, whereas the latter focuses on man invoking hope as an unconditional act ${ }^{22}$. Hope is

MAXIMUS THE CONFESSOR, Epistolae, in J.P. Migne, PG., vol. 91, col. 364-650, here Epistola XVI / Epistle XVI col. 579: "Hence, let's not become weaker in hardship, honorable father, knowing that misfortune works in patience, patience in testing, and testing in hope, and hope does not bring on shame, providing the kindness for which we suffer." ("Ne ergo deficiamus in tribulationis, venerande Pater, quos non lateat tribulationem patientiam operari; patientiam autem, probationem; probationem vero spem; spem autem, non confundere: quae firmam habeat, eorum nomine quae perpetimur, aeternorum bonorum beatam possessionem ac dulcedinem")

16 J.C. LARCHET, Teologia bolii / The Theology of Illness, Sibiu, Oastea Domnului Publishing House, 1997, p. 58.

17 ST. Augustine, De civitate Dei, in J.P. Migne, PL. vol 41, col. 13-804, here col. 21: "Nam sicut sub uno igne aurum rutilat, palea fumat; et sub eadem tribula stipulae comminuuntur, frumenta purgantur; nec ideo cum oleo amurca conlunditur, quia eadem preli pondere exprimitur: ita una eademque vis irruens bonos probat, purificat, eliquat; malos damnat, vasiat, exterminat"; also see Ioan TURCU, Suferinţa în concepţia laică şi cea creştină / Suffering in Laic and Christian Acceptance, Bucharest, 1931, p. 147.

${ }^{18}$ J.C. LARCHET, Dumnezeu nu vrea suferința omului / God Doesn't Want Man's Suffering, p. 129.

${ }^{19}$ H. VLACHOS, Psihoterapie ortodoxă / Orthodox Psychotherapy, p. 145.

${ }^{20}$ Viktor FrAnKL, La soferenza di una vita senza un senso. Psihoterapia per l'uomo d'ogii / The Suffering of a Life Without Meaning. Psychotherapy for the Contemporary Man, Turin, Elle Di Ci Editrice, 1992, p. 92.

${ }^{21}$ M. CHIODI, Etica de la Vita / The Ethics of Life, p. 363.

${ }^{22}$ Gabriel MARCEL, Homo viator, Borla, Rome, 1980, p. 57. 
man's answer to experiencing suffering. Hope must not be mistaken for the optimism according to which suffering will come to an end, but true hope goes beyond any condition and determined waiting ${ }^{23}$, thus using patience to get rid of any hopeless thought and assuming the conversion to a Christian life ${ }^{24}$. Suffering, illness, misfortune can become a genuine way of knowing God when man acknowledges the spiritual dimension of his existence. Pain is a new revelation of Christ in $\operatorname{man}^{25}$. Irrespective of who undergoes this process: youth, adults and the old, to all, suffering and misfortune can turn into reasons for profound meditation and repentance ${ }^{26}$, and, above all, a good opportunity to strengthen faith. By suffering, we remember God, we relate to Him, and we honor the great charism of prayer $^{27}$ and repentance. It is this very belonging to God through faith that gives man the courage to face and endure suffering, considering suffering as a means of consolidation, not in the sense of Stoicism, but in the sense that these are given to man as divine righteousness and pedagogy ${ }^{28}$. Saint Cyprian of Carthage, talking about the difference between Christians and pagans when enduring suffering, says that, for those who are not familiar with the power of faith, pain and illness are a means of enhancing faith ${ }^{29}$. Thus, there is a sort of divine pedagogy, according to which being put to the test is necessary to all, for spiritual practice:

\begin{abstract}
"Being tested - says Saint Isaac of Syria - is useful to any man (...) Those who are in need are being tested, so that they thrive in their richness; the lazy, so that they stay away from harm; the sleepy, so that they urge themselves to wake up; those who are far, so that they get closer to God; the house dwellers, so that they enter the house with courage. No unskilled son receives the wealth of his father's house before he is capable of using it. That is why God first tests people, making them experience hardship, and only then does He show them the $\operatorname{gift}^{30}$."
\end{abstract}

St Basil the Great, experiencing suffering himself, says that God allows suffering, misfortune and wanting as a test through which man can regain hope, faith, patience, the capability of being silent and dispassionate. Their purpose is to make men even brighter and worthier of an even greater reward, for those who bear them and overcome them spiritually:

\footnotetext{
${ }^{23}$ Ibidem, 157.

${ }^{24}$ Pr. prof. dr. Ioan C. TEȘU, Necazurile şi încercările, căi spre mântuire. Accente hrisostomice / Misfortune and Tests, Paths to Redemption. Chrisostomic Accents, in the Annals of "Al. I. Cuza" University of Iași, vol. 12, Teologie Ortodoxă / Orthodox Theology, p. 93-110, here p. 98.

${ }^{25}$ H. Vlachos, Psihoterapie ortodoxă / Orthodox Psychotherapy, p. 145.

${ }^{26}$ Ioan C. TEȘU, Necazurile şi încercările... / Misfortune and Tests..., p. 102.

${ }^{27}$ H. VLACHOS, Psihoterapie ortodoxă / Orthodox Psychotherapy, p. 146.

${ }^{28}$ ST. JOHN Chrysostom, Epistolae ad Olympiadem I, PG. vol. 52, col. 553: "Si igitur nunc cum molestiis laetos quoque successus subducere volueris, si non multa signa et miracula, at multas tamen res miraculis non dissimiles conspicies, quae quidem ingentis Dei providentiae atque auxilii perspicus argumenta sint". ("So, if you want to assess the good deeds and the bad ones, that occur nowadays, you will see, if not omens and miracles, many deeds resembling miracles, untold signs of God taking great care and of His help.")

${ }^{29}$ St. Cyprian of Carthage, De Mortalitate, in J.P. Migne, PL. vol. 4, col. 383-602, here ch. 13, col. 591B: "Hoc denique inter nos et caeteros interest, qui Deum nasciunt, quod illi in adversis queruntur et murmurant, nos adversa non avocant a virtutis et fidei veritate, sed corroborabt in dolore"; "What distinguishes us from those who do not know God is that the latter complain and revolt in misfortune, whereas, for us, misfortune, far from making us turn away from true courage and true faith, strengthens us in pain.")

${ }^{30}$ St. ISAAC OF SYRIA, Cuvinte despre nevoinţe / On Needing, in Filocalia Română / Romanian Philocalia, Bucharest, The Biblical Institute Publishing House, 1981, vol. 10, pp. 251-252.
} 
"The storm at sea - says St Basil - tests the captain of the ship, the stadium tests the athlete, the battle tests the general, misfortune tests the spiritual strength of man, temptation tests the Christian. Hardship tests souls just like fire tests gold ${ }^{31}$."

Suffering has this therapeutic power to push the sinner away from what is ephemeral and lacking value in the world, unties him from earth and makes him mature enough to seek for the heavenly kingdom ${ }^{32}$ :

\begin{abstract}
"You are poor. Don't be sad! Because too great sadness becomes reason to sin; sorrow clouds the mind, confusion mixes everything up and puzzlement breeds ingratitude. But have faith in God! Should God not see your distress? He holds your nourishment in His hand, but $\mathrm{He}$ postpones giving it to you so that He might test your strength, know your thoughts, making sure they do not belong to the evil and the discontent. For those, as long as they are fed, they praise, they flatter, and they never cease being amazed; if they are but little pushed away from the table, they throw insults just like rocks towards those they previously worshipped, in pleasure, as if they were $\operatorname{God}^{33}$."
\end{abstract}

In such a situation, illness is beyond pedagogical research and the person enduring it with patience and in gratitude towards God is granted the right to ascesis and suffering, or, even more so, he reaps the fruit of salvation out of his patience ${ }^{34}$.

\title{
2. THE PEDAGOGICAL ROLE OF SUFFERING
}

The pedagogical role of suffering also arises from the fact that it shows us that sin is at work within us, that we have strayed away from God's protective love, thus risking our own redemption. For example, we can simply notice that, holding our hand above fire, we will definitely get burnt, we will fell a sting and our first reaction will be to pull our hand back, away from the fire. This means that our previous action, that of putting our hand over the fire was wrong and the pain that ensued showed that to us. And if we hadn't felt the pain, the suffering caused by the fire, we would have risked getting our hand and body burnt, thus losing it all. Hence, this is how suffering reveals itself as the first messenger of the danger we find ourselves in, the danger of destruction when committing certain deeds.

The same meaning is to be found in the suffering that is brought upon people, namely to show them that their being struggles in an environment inconsistent with its natural state and place and that is why it fights through pain so as not to deviate from its ontological becoming. Only in Christ can man return to his real nature, as it was made by

\footnotetext{
${ }^{31}$ ST. BASILIUS Magnus, Homilia dicta Tempore Famis et siccitatis, in J.P. Migne, PG. vol. 31, col. 303D327C, here col. 318C: "Nam nauclerum tempestas, athleam stadium, imperatorem acies, magnanium virum calamitatis, Christianum tentatio probat et examinat. Atque ut ignis aurum, ita res adversae animam probat".

32 Nicolae BALCA,"Sensul suferinţei în creştinism / The Meaning of Suffering in Christianity”, in: Studii Teologice, / Theological Studies no. 3-4(1957), p.155-176. p. 170-171.

${ }^{33}$ St. Basilius Magnus, Homilia dicta Tempore Famis et siccitatis, col. 318CD: "Puper es? Cave animum abjicias. Nam nimia tristitia causa fit peccati, quod demergat mentem maeror, inducatque vertiginem desperatio, et vitium ingrati animi pariat consilii inopia. Sed spem habeto in Deum. Nunquid enim: non videm angustiam? Habet cibum in manibus: sed difert largitionem, ut probet tuam constantiam, ut animum agnoscat, sitne intemperantibus et ingratis consimilis. Ili enim, dum in ore sunt cibi, benedient, adulantur, supra modum admirantur: paululum vero dilata mensa, blasphemiis velunt lapidus inpetunt eos quos aliquanto ante aeque ac Deum propter voluptatem colebant":

${ }^{34}$ Ioan C. TEȘU, Bolile-’Divina filozofie... / Illnesses - Divine Philosophy ..., p. 20.
} 
God before the beginning of time, when He thought of making man in His divine resemblance and face, and discovering man's nature is becoming into being ${ }^{35}$.

Ultimately, suffering has the power to transform people. Those who used to indifferently pass by their grieving fellowmen, after having experienced hardship or severe illness, changed their behavior. They became good Samaritans and showed mercy in their relations to others; they are capable not only of sympathy, but also of sacrifice for the wellbeing of their fellow-men. Suffering bestows true value on life. It teaches us the lesson of love. More so than all didactic theories and ambitions, experiencing suffering gives man a real and healthy education. Lessons learnt through suffering are stronger and truer than all pedagogical principles. The latter are just as often and just as substantially corrected by life experience $^{36}$.

Out of His endless love for us, God does not want to allow our love to be squandered into sin and this is why He resorts to all solutions to turn it back to its real path. Christ came precisely for those who had strayed away from Him, He suffered for them, He died and came back to life, but, if they do not understand that, God keeps them wallowing in the suffering that they bring upon themselves, in the hope of the Gospel Father that they will at some point return home.

\section{THE SACRIFICIAL ASPECT OF SUFFERING. ON MARTYRS}

The sacrifice expresses life's profound richness, which offers or offers itself in order to surpass oneself and feel fulfilled in the communion with God, with one's fellowmen and with the entire existence. Man gives up "having" so as to become complete in "being," that is in his own being. He searches for himself in offering himself and, sometimes, he finds himself by creating himself, even at the cost of his own life ${ }^{37}$. The martyr offers himself and everything he has as a sacrifice to God. By this offering, he turns even death into sacrifice ${ }^{38}$.

Sacrifice, by the act of giving up, of abdicating the self, of offering, implies suffering. It is more acutely felt according to the motivation of sacrifice and our own capability of sacrificing. This sacrificing state should be the very reason of the existence of Christianity, which has the Holy Trinity as the ultimate model. Out of immense love for people, God did not shy away from sacrificing His only Son for our redemption (John III, 16). Thus, sacrifice is exclusively based on love, the only one to give higher purpose to our deeds, as it mimics Christ the Saviour. Martyrs prove that love for God is stronger than fear of death ${ }^{39}$. In this respect, (Apostle) Saint Paul writes to Christians in Rome, the city to be martyred by beheading:

"Who will separate us from Christ's love? Misfortune, or hardship, or persecution, or hunger, of lack of clothes, or danger, or the sword (...). As it is ordained, it is for You that we are

\footnotetext{
${ }^{35}$ Celălalt Noica / The Other Noica, Mărturii ale Monahului Rafail Noica însoţită de câteva cuvinte de folos ale Părintelui Simeon / Testimonies of Monk Rafail Noica, accompanied by some useful words by Father Symeon, Anastasia Publishing House,1994, p. 46.

${ }^{36}$ Ioan G. COMAN, Frumuseţile iubirii de oameni în spiritualitatea patristică / The Beauty of Loving One's Fellowmen in Patristic Spirituality, Timişoara, The Banat Metropolis Publishing House, 1988, p. 282.

${ }^{37}$ Constantin GALERIU, Jertfă și răscumpărare / Sacrifice and Redemption, Bucharest, Harisma, 1991, p. 11.

${ }^{38}$ Henri Crouzel, Origen, Sibiu, Deisis, 1999, p. 200.

${ }^{39}$ Michail GaLENIANOS, "Valoarea martiriului în vremuri de persecuție conform Sf. Ioan Gură de Aur" / "The Value of Martyrdom During Persecution Times According to St. John Chrysostom", in Eucharist and Martyrdom, Alba-Iulia, Reîntregirea, 2014, p. 143-154, here p. 146.
} 
killed every day, considered to be sheep for the slaughter. But, in all these, we are ever more victorious through the One Who loved us" (Romans 8, 35-37), that is through Jesus Christ.

Complete dedication is included - although it does not necessary imply martyrdom. Indeed, within martyrdom, there is total sacrifice, stating at the same time a profound consciousness of transcendence. The original meaning of the concept of martyrdom is that of an authentic witness ${ }^{40}$ of truth, of testifying truth with one's entire being under any circumstances and at any risk ${ }^{41}$.

\begin{abstract}
"If being a martyr - Clement of Alexandria says - consists in acknowledging God, then any soul that lives in pure life and knowing God, obeying the commandments, is a martyr through life and word, because, when he parts with his body, he effuses, like blood, his faith upon his departure from here, the same way he effused it during his entire life ${ }^{42}$."
\end{abstract}

Complete dedication in sacrifice and service does not mean self-dissolution and annulment of the individual, but, on the contrary, affirmation. Sacrifice gives the individual new content and glow; it transfigures him, enriching $\mathrm{him}^{43}$; it makes the "face" evolve to "resembling" the Archetype, God. Renouncing the self does not mean forgetting the self, but the self, living in the other, in "you," it is absolution from the useless concrete, the material, because of which we cannot follow Jesus.

Self-love, selfishness is a prison of the self, which makes man a guardian "guardian of nothingness" and a "being towards death." There is no death in dedication out of love, as life extends from man to man, passed down from generation to generation ${ }^{44}$. And, within the one to sacrifice himself for Christ, death works in life, as he completely offers himself to God, and He descends upon him, dwells within him, thus opening the gates to eternal life. It, therefore, confirms what (Apostle) Saint Paul said, that "I no longer live myself, but it is Christ who lives within me." Suffering or experiencing pain because of faith as conviction, is part of the invitation to follow Christ: "Whoever wants to follow Me, renounce yourselves, pick up your cross and follow Me.” (Mc.8,34).

Martyrdom is the climax of ultimate fulfilment ${ }^{45}$. The most authentic understanding of suffering within Christianity can be found in its relation to the Martyr ${ }^{46}$. Martyrdom is the most eloquent expression of the state of suffering transfigured through faith and which is entailed not by means of human fight, but by the presence of the divine grace that takes hold of the soul and renders human life divine. Acknowledging Christ during those times meant taking on atrocious suffering: it meant not only losing your fortune, your social status, but also endangering your family's future and being physically and morally subjected to

${ }^{40}$ Laurentius SoBCO, Noul martiriu: un scurt moment de eroism sau un mod de viață / The New Martyrdom: A Short Instance of Heroism or a Lifestyle, in "Eucharist and Martyrdom", Alba-Iulia, Reîntregirea, 2014, p. 155170, here p. 156.

${ }^{41}$ C. GALERIU, Jertfă şi răscumpărare / Sacrifice and Redemption, p. 33-34.

${ }^{42}$ Clement OF AleXANDria, Stromata, IV, 4, in J.P. Migne, PG., vol. 8, col. 685 - 1382, here col. 1227D: "Si autem Deo confiteri sit martyrium, quaecunque anima pure cum agnitione Dei vitam instituit et praeceptis paruit, ea quidem vita et sermone est martyr, quomodocunque liberetur a corpore; fidem scilicet, tanquam sanguinem, per totam vitam et etiam in exitu, profundes".

${ }^{43}$ C. GALERIU, Jertfă și răscumpărare / Sacrifice and Redemption, p. 34.

${ }^{44}$ Elena Solunca MoISE, Cuviinţa Tainei / The Propriety of Sacrament, 1996, p. 116.

${ }^{45}$ Nicolae Mladin, Asceza şi Mistica paulină / Ascesis and St. Paul's Mystique, Sibiu, Deisis, 1996, p.163.

${ }^{46}$ Ilie Moldovan, „Viața, suferința și moartea în condiția spirituală a existenței creștine” / "Life, Suffering and Death in the Spiritual State of Christian Existence", in Sensul vieții, al suferinței și al morții / The Meaning of Life, Suffering, and Death, Alba-Iulia International Symposium, February 29 - March 2, 2008, Alba-Iulia, Reîntregirea Publishing House, 2008, p. 69-87, here p. 77. 
unimaginable torture. A martyr's sacrifice sheds light, above all, on a profound faith in God, that is not only intellectual, rational acceptance of His existence and discovery, but a living faith, a personal adhesion which implies man's entire existence. Based on this faith, the martyr places all his hope in God and gladly and confidently leaves behind what he treasures the most ${ }^{47}$.

'Martyrial Acts' describe, in this respect, tortures that man alone, without Christ's help, could not have endured. It is almost unbelievable how, old people, children, and women gladly preferred dying in those atrocious torments, rather than deny faith in Christ. This is the proof of the most genuine love for Christ. "It is very pleasurable (Saint Cyril of Alexandria says) to suffer in the name of Christ, and danger is sweet, when the reason behind it is love for $\operatorname{God}^{48}$." We find the same information in the Martyrial Acts:

\footnotetext{
"We worship Christ because He is the Son of God, and we love martyrs for being worthy, as they are the disciples and imitators of God, for their unsurpassed love for their Lord and Teacher.' May we become part of this and disciples together ${ }^{49}$."
}

Precisely because martyrial sacrifice is the proof of the highest form of love, it can become the noblest level of holiness. Following Christ up to the voluntary sacrifice of one's life, the martyr, more than any other person, becomes consecrated in the sense of holy and one with the Embodied Logos up to resembling Him $^{50}$ and worthy of Paradise happiness.

\begin{abstract}
"So, casting out (persecuting) witnesses (martyrs) - Saint Gregory of Nyssa states - inflicted by tyrants is, for now, painful to the senses according to the face it showed, but the end of those experiencing it surpasses all happiness ${ }^{51}$." In the same respect, Saint Ambrose of Milan also stated: "He who, even upon his very death, acknowledges Our Lord Jesus, must be worthy of dwelling in heaven ${ }^{52}$."
\end{abstract}

For three centuries, millions of saints, of martyrs may have been tortured, killed in indescribable torment, some of them remaining anonymous for us. Most of the times, the thought that Christ Himself was the one to suffer for them made them overcome the suffering of sudden or lingering death. Their faith was strong amidst the most terrible torment and suffering, considering that Christ was with them and He will suffer alongside them ${ }^{53}$. Christus in martyre est! The belief that Christ Himself is the one to suffer is proof

\footnotetext{
47 Sandro SpInSANTI, "Martire" / "Martyr," in Stefano De Fiores E Tullo Goffi, Nuovo Dizionario di Spiritualita / New Dictionary of Spirituality, Turin, San Paulo Publishing House, 1985, p. 903-917, here p. 909.

${ }^{48}$ ST. CYRIL OF AlEXANDRIA, In Ioannis Evangelium, Liber X, in JP. Migne, PG., vol. 74, col. 283-444, here col. 407C: "Suavissimum igitur est pati propter Christum, et dulce periculum, cum eius inferendi causa est erga Deum dilectio".

49 ACtele Martirice / MartyriCAL ACTS, De martyrio Sancti Polycarpi, in JP. Migne, PG., vol. 05, col. 10291046, here col. 1042D: "Illum enim, utpote Filium Dei adoramus; martyres vero tanquam Domini discipulos et imitatores merito diligimus, propter illorum eximiam erga regem ac magistrum suum benevolentiam; quorum utinam et nos siamus consortes ac condiscipuli".

${ }^{50}$ S. SPINSANTI, "Martire" / "Martyr," p. 909.

${ }^{51}$ St. GREgORY OF NYSSA, De Beatitudinibus, in JP. Migne, PG., vol. 44, col. 1194-1302, here Oratio VIII, col. 1294D-1295A: "Itaque persecutionis, qua martyres a tyranis agitandur, species quidem prout prima fronte apparet, sensui acerba esse videtur, sed id quo spectant ea quae sunt, omnem beatitudinem superat".

${ }^{52}$ ST. Ambrose OF MILAN, Epistolae in duas classes distribuitae, Epistola LXXI / Epistle LXXI, in JP. Migne, PL., vol. 16, col. 1241B-1243B, here col. 1243A: "Itaque is qui sub ictu mortis convertitur, et contitetur Dominum Iesum, mereatur incolatum paradisi".

${ }^{53}$ Ioan RĂMUREANU, Introducere Generala / General Introduction, in "Actele martirice"/ "Martyrial Acts", in Col. 'Părinți și Scriitori Bisericești' / 'Church Fathers and Writers', vol. 11, Bucharest, IBMBOR / BROCMI, 1982, pp. 5-16, here p. 6.
} 


\title{
that martyrial sacrifice is possible due to the man-God synergy ${ }^{54}$. This is how we can explain
} superhuman courage and perseverance in enduring pain ${ }^{55}$ :

\begin{abstract}
"While preaching God's word to the people, preaching virtue, Peter inflamed the souls of the pagans, who began looking for him. But Christian souls asked him to withdraw from the public for a while. And, although he was willing to suffer, he yielded to the people's pleas. For he was asked to wait for now, to be able to teach and empower the people. But why dwell on it any longer? At night, as he was trying to leave the city, he saw Christ coming into the city through the gates and he asked Him: My Lord, where are You going? Christ answered: To be crucified again. Peter understood that the divine answer entailed his own cross. For Christ could not be crucified again, as, in receiving death, He had parted with the suffering of the body. What died, died away from sin once and for all, and what lived, lives for God (Rom. 6, 10). Thus, Peter understood that Christ will have to be crucified again through His servant. Hence, he willingly turned back, answered Christians' question on his way, and, being immediately arrested, honored Christ through crucifixion. So, you see, Christ wants to suffer through His servants ${ }^{56}$."
\end{abstract}

\section{Saint Ignatius of Antioch, martyred in Rome in 107, wrote to the Romans:}

"I write to the Churches, and impress on them all, that I shall willingly die for God, unless you hinder me. I beseech of you not to show an unseasonable good-will towards me. Allow me to become food for the wild beasts, through whose instrumentality it will be granted me to attain to God. I am the wheat of God, and let me be ground by the teeth of the wild beasts, that I may be found the pure bread of Christ. [...] Oh, if I could experience the wild beasts that are in store for me, I pray I find them ready! I will even bait them, so that they might eat me presently, unlike others who, being fearful, were left untouched. And even if they do not want to, I will make them. Forgive me, I know what is useful for me. I now begin to be a disciple. I do not covet anything seen or unseen to reach Christ. The fire, the cross, the many wild beasts, being cut, torn apart, having my bones scattered [...] may the devil's evil punishment come over me. The time of my birth is drawing near, I only need to reach Christ [...] I would rather die for Jesus Christ than rule up to the ends of the earth. [...] I am seeking for the One who died for us and came back to life. Forgive me, my brothers, do not prevent me from living within Christ by not wanting me to die. Do not give the one who wants to be God's to the world and do not fool him with the material. Let me receive the pure light, once I get there, I will be a man. Allow me to be an imitator of Christ's suffering ${ }^{57}$."

${ }^{54}$ I. MoLdOVAN," Viața, suferința și moartea..." / "Life, Suffering and Death...”, p. 78.

55 S. SPINSANTI, Martire / Martyr, p. 908.

${ }^{56}$ St. Ambrose OF MILAN, Epistolae in duas classes distribuitae, Epistola XXI / Epistle XXI, in JP. Migne, PL., vol. 16, col.1002CD-1018D, here col. 1010D-1011AB: "Idem Petrus postea cum praecepta Dei populo seminaret, doceret catimoniam, excitavit animos gentilium: quibus eum quaerentibus, christianae animae deprecatae sunt, ut paulisper cederet. Et quamvis esset cupidus passionis, tamen contemplatione populi precantis inflexus est; rogabatur enim ut ad instituendum et confirmandum populum se reservaret. Quid multa? Nocte muros egredi coepit, et videns sibi in porta Christum occurrere, urbemque ingredi, ait: Domine: quo vadis? Respondit Christus: Venio interum crucifigi. Intellexit Petrus ad suam crucem divinum pertinere responsum; Christus enim non poterat interum crucifigi, qui carnem passione susceptae mortis exuerat: «Quod enim mortuus est, peccato mortuus est semel: quod autem vivit, vivit Deo (Rm. VI, 10). » Intellexit ergo Petrus quod iterum Christus crucifigendus esset in servulo. Itaque sponte remeavit, interrogantibus Christianis responsum reddidit, statimque correptus, per crucem suam honorificavit Dominum Iesum. Videtis igitur quod in servulis suis pati velit Christus".

${ }^{57}$ St. Igantius of ANTIOCH, Ad Romanos, in JP. Migne, PG., vol. 5, col.802-818, here 807B; 810B; 811A; 814A: "Ego omnibus Ecclesiis scribo, et mando omnibus, quod voluntarius pro Deo moror, si modo non prohibueritis. Obsecro vos ne intempestiva benevolentia erga me sitis. Sinite me ferarum escam fieri, per quas licet deum adipisci. Frumentum sum Dei, dentibus bestiarum molor, ut mundus panis Dei inveniar. [...] Utinam fruar bestiis mihi pratis: quas et opto veloces mihi inveniri; quas et blanditiis demulcebo, ut citius me devorent; non ut quosdam veritae non attigerunt. Sed et ipsae volentem nolint, ego vi adigam. Ignoscite mihi: quid mihi 
This joy and strength in dying for Christ, who suffered and was victorious for us, is common and characteristic to all Christian martyrs. It is not defiance to state authority, but rather a powerful statement of Christian identity. Before being citizens of a socio-political and administrative organization, such as the empire during the primary Church, Christians are citizens of the Kingdom of Heaven. Christ is the true King and Lord of Christians ${ }^{58}$.

\begin{abstract}
"For us - Tertullian says - it is a real war when we are brought before judges, because there we must fight for truth, at the risk of dying. But victory lies in achieving the goal you have been fighting for. This victory entails the glory of being to God's liking and gaining eternal life. But we are crushed! This is true, but after having won. Thus, when we die, we are victorious, when we are crushed, we consider ourselves absolved. Now, you can call us many names, for we are tied at the half of an axis and burnt with brushwood laid around us. This is the coat of our victory, this is the medal on our chest, this is the chariot where we celebrate our triumph ${ }^{59}$."
\end{abstract}

The Church does not urge its followers to seek for suffering and death ${ }^{60}$, but, when faced with them, the martyrs endured them heroically, as a sacrifice in Christ's name. The martyrs are the expression of the fact that the Church is always in a state of sacrifice. The martyrs imitate not only Christ's suffering, but also His virtues. Christ's love and their love were one. They forgive their persecutors and pray for their absolution. Archdeacon Stephen, the first martyr to die under blows, says: "Lord, forgive them for this sin," thus sublimely following Christ crucified on the Cross. Furthermore, from the very first centuries of the Church, the martyr has been compared with the virtue of virgins' chastity, considering that the virtue of virgins' chastity implies bloodless martyrdom ${ }^{61}$.

Martyrdom also has the power of a Sacrament: it is the Baptism of the one who has not been baptized with water, but which brings him salvation ${ }^{62}$. From the very first days of Christianity, it was commonly acknowledged and believed that those who were about to be baptized, the catechumen, but who suffered martyrial death before being baptized with water, were acknowledged as being effectively baptized, due to the spilling of their own blood while acknowledging Christ ${ }^{63}$. Saint Gregory of Nazianzus confirms the validity and

utile sit ego novi; nunc incipio discipulus esse; nihil expetam visibilium et invisibilium, ut Iesum Christum assequar. Ignis, crux, ferarum concursus, sectiones, lanienae, assium discerptiones [...] et diaboli tormenta in me veniant, tantummodo ut Iesum nanciscar. [...]. Melius est mihi emori propter Iesum Christum, quam imperare finibus terrae. [...]. Dominum desidero, illum quaero, qui pro nobis mortuus est et resurrexit. Ignoscite mihi, fratres; ne mihi impedimento sitis, quominus ad vitam perveniam. Iesus enim est vita fidelium. Ne me velitis mori: mors namque est, vita sine Christo. Cumque cupiam Dei esse, ne me mundo condonetis. Sinite me purum lumen haurire. Cum illic fuero, homo Dei ero. Permittite mihi, ut aemulator sim passionis Christi Dei mei”.

58 Adrian LEMENI (coord), Apologetica Ortodoxă / Orthodox Apologetics, vol. I, Bucharest, Basilica, 2013, p. 131.

59 Tertullian, Apologeticus adversos Gentes Pro Christianis, in JP. Migne, PL., vol. 01, col. 305-604, here col. 598B- 599A: "Praelium est nobis quod provocamur ad tribunalia, ut illic sub discrimine capitis pro veritate certemus. Victoria est autem pro quo certaveris, obtinere. Ea victoria habet, et gloriam placendi Deo, et praedam vivendi in aeternum. Sed obducimur, certe cum obtinuinus: ergo vicimus, cum occidimur: denique evadimus, cum obducimur; licet nunc sarmeticios et semaxios appelletis, quia ad stipitem dimidii axis revincti sarmentorum ambitu exurimur. Hic est habitus victoriae nostrae; haec palmata vestis, tali curru triumphamus".

${ }^{60}$ Valer BEL, "Sensul creștin al martiriului" / "The Christian Meaning of Martyrdom", in $S t u d i$ a Universitatis Babeş-Bolyai.Theologia Orthodoxa, no. 1(2012) p. 109-112, Cluj, 2012, here p. 112.

${ }^{61}$ S. SPINSANTI, "Martire" / "Martyr," p. 910.

${ }^{62}$ Teodor M. POPESCU, "Moartea şi învierea Mântuitorului în credinţa vechilor creştini” / "Christ's Death and Resurrection in the Faith of Old Christians", in Ortodoxia, VII, no. 2, (1955), p. 163-181, here p.173.

${ }^{63}$ S. SPINSANTI, "Martire" / "Martyr," p. 909. 
the existence of this baptism of martyrs who, until the moment of their martyrdom, have not been baptized with water:

"I also know of the fourth Baptism, the one through martyrdom and blood, in which Christ was baptized, and which is more valuable than others, as it is not tainted by later sins ${ }^{64}$." "According to Gospel laws - Origen also confirms it - we cannot be baptized twice: with water and spirit for our sins to be forgiven, but, instead, we are allowed the baptism of martyrdom. For this is how it is called, as it can clearly be seen in the fact that to the word 'you may drink the glass that I shall drink' the following is added 'or be baptized in the same baptism that I am baptized.' And there is another mention that says: 'I shall be baptized in one baptism and I cannot wait for it to be fulfilled!' ${ }^{65}$. "Being baptized in our blood and absolved of any wrong-doing, let's spend our time next to the altar in heaven, together with the ones that fought beside us ${ }^{66}$."

\title{
CONCLUSION
}

All these considered, we can easily understand why, from the very beginning, the Church naturally acknowledged the worthy values of martyrdom and its effects in rendering life holy. From the same perspective, the Holy Fathers ${ }^{67}$ urge us to consider the suffering undergone by the martyr as no more and no less than stages of Christ's fight against the powers of evil and to look up to these battles that Christ is fighting within His believers. Through this, we can acknowledge God's presence at work within man, not just as a presence invoked for eternity, but as one at work during history with eschatological opening $^{68}$.

\begin{abstract}
“As, with Christ's help, the saints' patience rendered all these tyrannical punishment methods pointless, the devil plotted other imaginings: imprisonments in dark and horrible places, putting feet inside logs, and tightening them up to the fifth hole, as well as other types of torture, that angry and devil-like servants used to inflict on the arrested. Thus, many died asphyxiated in the dungeon, namely all those whom God chose to end their days so that His glory be praised ${ }^{69}$."
\end{abstract}

This is why Christian martyrdom is, at the same time, an eschatological sign as well, which distinguishes it from other forms of martyrdom, by the fact that it states life's fullness by anticipating, in history, the reality of the eternal kingdom of Heaven. In the Holy

\footnotetext{
${ }^{64}$ St. GRegORY OF NAZIanZus, Oratio XXXIX, In Sancta Lumina, in JP. Migne, PG., vol. 36, col. 335-360, here col. 355A: "Quartum etiam baptismi genus novi, nempe quod martyrio et sanguine comparatur, quo ipse quoque Christus baptizatus est, et quidem eo caeteris augustius, quod nullis postea sordibus contaminatur".

${ }^{65}$ ORIGEN, Exortatio ad Martyrium, in JP. Migne, PG., vol. 11, col. 563 -650, here col. 599C-602A: "Nos autem juxta evangelicas leges iterum non posse baptizari aqua et Spiritu in remissionem peccatorum, sed datum nobis esse martyrii baptisma; sic enim vocatur, ut ex eo patet quod his verbis: «Potestis bibere calicem quem ego bibo?» subiungitur: «Aut baptismo quo ego baptizor, baptizari? » Alibi etiam dictum est: «Baptismo habeo baptizari et quamodo coarctor usque dum perficiatur»

${ }^{66}$ Ibidem, col. 615B: "Ideo servati ut proprio sanguine abluti et omni peccato mundati apud coeleste altare cum iis qui similiter certaverint, conversemur".

${ }^{67}$ St. Augustine, Sermones de Sanctis, Sermo 313, in JP. Migne, PL. vol. 38, col. 1247 - 1484, here col. 1423.

${ }_{68}^{6}$ A. LEMENI, Apologetica Ortodoxă / Orthodox Apologetics, I, p. 126.

${ }^{69}$ Eusebiu de Cezarea, Historia Ecclesiastica, in JP. Migne, PG., vol. 20, col. 09- 904, here Liber V, col. 419B: "Porro cum universa tyrannorum tormenta per martyrum constantiam a Christo essent retusa, alias machinas diabolus excogitavit, ut scilicet in obscurissimum ac molestissimum carceris locum coiicerentur, utque pedes in nervo ad quintum usque foramen distensos haberent, ac reliqua huiusmodi cruciatuum generas perferrent, quibus ministri, utpote infensi et a daemone incitati, vexare inclusos consuevereunt. Adeo ut ex eorum numero quamplurimi in carcere suffocati interieriunt, quos scilicet Deus, qui suam in omnibuz gloriam ostendit, hoc mortis genere defungi loluerant".
} 
Fathers' view, the persona of Christ the Savior is a living reality in the life of the believer, manifested in the continuous and fulfilling action of the Holy Spirit. Only at the extent to which this reality is lived as such by the believer as early as his life here, only at this extent is it possible to gain the Kingdom of Heaven and union with $\operatorname{God}^{70}$.

\section{REFERENCES}

[1] Actele Martirice / Martyrical Acts, De martyrio Sancti Polycarpi, in JP. Migne, PG., vol. 05, col. 1029-1046.

[2] BALCA, Nicolae, Sensul suferinţei în creştinism / The Meaning of Suffering in Christianity”, in „Studii Teologice" / "Theological Studies", no. 3-4(1957), p.155-176.

[3] BEL, Valer, Sensul creștin al martiriului / The Christian Meaning of Martyrdom, in "S t u d i a Universitatis Babeş-Bolyai.Theologia Orthodoxa", no. 1(2012) p. 109-112.

[4] Celălalt Noica / The Other Noica, Mărturii ale Monahului Rafail Noica însoțită de câteva cuvinte de folos ale Părintelui Simeon / Testimonies of Monk Rafail Noica, accompanied by some useful words by Father Symeon, Anastasia Publishing House, 1994.

[5] CHIODI, Maurizio, Etica de la Vita / The Ethics of Life, Milan, Edizioni Glossa, 2006.

[6] [6] CHrILĂ, Pavel \& com, Principii de bioetică. O abordare ortodoxă / Principles of Bioethics. An Orthodox Approach, Bucharest, Christiana Publishing House, 2008.

[7] Clement of AleXAndria, Stromata, IV, 4, in J.P. Migne, PG., vol. 8, col. 685 - 1382.

[8] Coman, Ioan G., Frumuseţile iubirii de oameni în spiritualitatea patristică / / The Beauty of Loving One's Fellowmen in Patristic Spirituality, Timişoara, The Banat Metropolis Publishing House, 1988.

[9] CROUZEL, Henri, Origen, Sibiu, Deisis, 1999.

[10] Eusebiu DE CEZAREA, Historia Ecclesiastica, in JP. Migne, PG., vol. 20, col. 09 - 904.

[11] St. Augustine, Sermones de Sanctis, Sermo 313, in JP. Migne, PL. vol. 38, col. 1247 - 1484.

[12] St. Augustine, De civitate Dei, in J.P. Migne, PL. vol 41, col. 13-804.

[13] FranKL, Viktor, La soferenza di una vita senza un senso. Psihoterapia per l'uomo d'ogii / The Suffering of a Life Without Meaning. Psychotherapy for the Contemporary Man, Turin, Elle Di Ci Editrice, 1992.

[14] Galenianos, Michail, Valoarea martiriului în vremuri de persecuție conform Sf. Ioan Gură de Aur / The Value of Martyrdom During Persecution Times According to St. John Chrysostom, in "Eucharist and Martyrdom”, Alba - Iulia, Reîntregirea, 2014, p. 143-154.

[15] GALERIU, Constantin, Jertfă şi răscumpărare / Sacrifice and Redemption, Bucharest, Harisma, 1991.

[16] LARCHET, Jean-Claude, Teologia bolii / The Theology of Illness, Sibiu, Oastea Domnului Publishing House, 1997, p. 58.

[17] LARCHET, Jean-Claude, Dumnezeu nu vrea suferința omului/God Does not Want Man's Suffering, Bucharest, Sophia, 2008.

[18] LemEnI, Adrian (coord), Apologetica Ortodoxă / Orthodox Apologetics, vol. I, Bucharest, Basilica, 2013.

[19] MARCEL, Gabriel, Homo viator, Borla, Roma, 1980.

[20] Mladin, Nicolae, Asceza şi Mistica paulină / / Ascesis and St. Paul's Mystique, Sibiu, Deisis, 1996.

[21] MoIse, Elena Solunca, Cuviinţa Tainei / The Propriety of Sacrament, 1996.

[22] Moldovan, Ilie, Viața, suferința și moartea în condiția spirituală a existenței creștine / Life, Suffering and Death in the Spiritual State of Christian Existence, in "Sensul vieții, al suferinței și al morții" / "The Meaning of Life, Suffering, and Death," Alba-Iulia International Symposium, February 29 - March 2, 2008, Alba-Iulia, Reîntregirea Publishing House, 2008, p. 69-87.

[23] ORIGEN, Exortatio ad Martyrium, in JP. Migne, PG., vol. 11, col. 563 -650.

[24] POPESCU, Teodor, Moartea şi învierea Mântuitorului în credinţa vechilor creştini / Christ's Death and Resurrection in the Faith of Old Christians in "Ortodoxia", VII, no. 2, (1955), p. 163-181.

[25] RĂMUREANU, Ioan, Introducere Generala / General Introduction, in "Actele martirice" / "Martyrial Acts", in: Colecția Părinți și Scriitori Bisericești / Religious Fathers and Writers Collection, vol. 11, Bucharest, IBMBOR / BROCMI, 1982, p. 05-16.

[26] REMETE, George, Suferinţa omului şi iubirea lui Dumnezeu / Man's Suffering and God's Love, Bucharest, Edit. Institutului Biblic și de Misiune al Bisericii Ortodoxe Române (de acum IBMBOR) / The Biblical and Romanian Orthodox Church Mission Institute (from now on BROCMI), 2005.

\footnotetext{
${ }^{70}$ St. SymeOn the New THEOLOGIAN, Cateheze, Scrieri II / Catechesis, Writings II, translation and introductory study by deacon Ioan I. Ică jr., Deisis Publishing House, Sibiu, 1999, p. 338
} 
[27] RiCOEUR, Paul, Flosofia della volonta. 1.Il voluntario e l'involuntario / The Philosophy of Will. 1. The Voluntary and the Involuntary, Genova, Marietti, 1990.

[28] St. IgAnTIUS OF ANTIOCH, Ad Romanos, in JP. Migne, PG., vol. 5, col.802-818.

[29] St. Ambrose of MILAN, Epistolae in duas classes distribuitae, Epistola LXXI / Epistle LXXI, in JP. Migne, PL., vol. 16, col. 1241B-1243B.

[30] St. AMBROSE OF MILAN, Epistolae in duas classes distribuitae, Epistola XXI / Epistle XXI, in JP. Migne, PL., vol. 16, col.1002CD-1018D.

[31] St. CyRIL OF AlEXANDRIA, In Ioannis Evangelium, Liber X, in JP. Migne, PG., vol. 74, col. 283-444.

[32] St. CyPrian of CARTHage, De Mortalitate, in J.P. Migne, PL. vol. 4, col. 383-602.

[33] St. GREGORY OF NYSSA, De Beatitudinibus, in JP. Migne, PG., vol. 44, col. 1194-1302.

[34] St. GREGORY OF NYSSA, Oratio XXXIX, In Sancta Lumina, in JP. Migne, PG., vol. 36, col. 335-360.

[35] St. John Chrysostom, Epistolae ad Olympiadem, in J.P. Migne, PG. 52, col. 542-623.

[36] ST. ISAAC OF SYRIA, Cuvinte despre nevoinţe / On Needing, in Filocalia Română / Romanian Philocalia, Bucharest, The Biblical Institute Publishing House, 1981, vol. 10, p. 251-252.

[37] St. MAXIMUS THE CONFESSOR, Epistolae, in J.P. Migne, PG., vol. 91, col. 364-650.

[38]St. Symeon the New Theologian, Cateheze, Scrieri II / / Catechesis, Writings II, translation and introductory study by deacon Ioan I. Ică jr., Deisis Publishing House, Sibiu, 1999.

[39] St. Basilius Magnus, Homilia dicta Tempore Famis et siccitatis, in J.P. Migne, PG. vol. 31, col. 303D$327 \mathrm{C}$.

[40] SoBCO, Laurentius, Noul martiriu: un scurt moment de eroism sau un mod de viață / The New Martyrdom: A Short Instance of Heroism or a Lifestyle, in "Eucharist and Martyrdom", Alba - Iulia, Reîntregirea, 2014, p. 155-170.

[41] SPINSANTI, Sandro, Martire / Martyr, in Stefano De Fiores e Tullo Goffi, "Nuovo Dizionario di Spiritualita" / "New Dictionary of Spirituality", Turin, San Paulo Publishing House, 1985, p. 903-917.

[42] TERRIN, Aldo Natale, Il dolore e la morte nelle religioni / Suffering and Pain in Religions, in "Sensul vieții, al suferinței și al morții" / "The Meaning of Life, Suffering and Death", Alba-Iulia International Symposium, February 29 februarie - March 2, 2008, Alba-Iulia, Reîntregirea Publishing House, 2008, p. 57-69.

[43] Tertullian, Apologeticus adversos Gentes Pro Christianis, in JP. Migne, PL., vol. 01, col. $305-604$.

[44] TEȘU, Ioan C., Necazurile şi încercările, căi spre mântuire. Accente hrisostomice / Misfortune and Tests, Paths to Redemption. Hrisostomic Accents, in the Annals of "Al. I. Cuza” University of Iaşi, vol. 12, Teologie Ortodoxă / Orthodox Theology, p. 93-110.

[45][TEȘU, Ioan C., Necazurile, durerile și suferințele - forme ale iubirii milostive a lui Dumnezeu / Misfortunes, Pain, and Suffering - Forms of God's Merciful Love, in "Teologie și Viața" / "Theology and Life", no. 9-12 (2012), p. 5-26.

[46] TettamanzI, Dionigi, Nuova Bioetica Cristiana / New Christian Bioethics, Turin, Piemme, 2001.

[47] TuRCu, Ioan, Suferinţa în concepția laică şi cea creştină / Suffering in Laic and Christian Acceptance, Bucharest, 1931, p. 147.

[48] Vlachos, Hierotheos, Psihoterapie ortodoxă - continuare și dezbateri / Orthodox Psychotherapy Continuation and Debates, Bucharest, Sophia, 2007. 